\title{
Study on Wave Reduction and Beach sand Capture Performance of Artificial Coral Reefs for In-situ Application
}

\author{
Sung-Hoon Hong", Tae-Yoon Kim, Yun-Shik Choi ${ }^{*}$, Jeong-Ho Kim, \\ Yong-Ju Kwon*, Si-Hyeon Lee*, Gwang-Soo Lee ${ }^{* *}$ and Soon-Chul Kwon ${ }^{*}$ \\ "Department of Civil and Environmental Engineering, Pusan National University, Busan, Korea \\ ${ }^{*}$ Han Ocean Corp., Busan, Korea

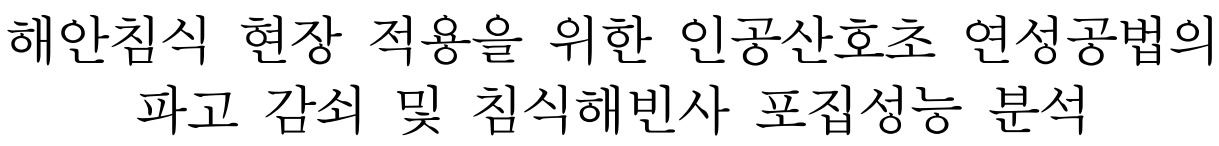 \\ 홍성훈 \\ *부산대학교 사회환경시스템공학과 \\ "(주)한오션
}

KEY WORDS: Coastal erosion 해안침식, Artificial coral reefs 인공산호초, Wave reduction 파랑감쇠, Sand capture 모래 포집, Beach sand 해빈사, Sediment budget 표사 수지

\begin{abstract}
Because of the increase in coastal erosion problems, many studies have been conducted to prevent coastline retreat by developing low-cost, highly effective countermeasures. We developed the artificial coral reefs (ACRs) method as part of this research trend. To verify its coastal protection performance, we carried out performance tests on its wave attenuation and beach sand capture ability, which are the key barometers for this newly developed technology. In this study, three different types of methods, including natural beach, TTP, and ACRs, were used to determine the coastal protection efficiency under both ordinary and storm wave conditions. Based on the results of this study, ACRs were found to have the best wave attenuation performance and captured more than $20 \%$ of the total erosion area. This means the ACR method can be applied as a reliable countermeasure to protect a coastal zone.
\end{abstract}

\section{1. 서 론}

해안지역에서 발생하는 침식은 단순하게 해안선의 후퇴에 따 른 국토면적의 소실을 의미할 뿐 아니라 해안의 가치를 하락시 켜 지역경제에 악영향을 미치며, 파랑 내습 시 완충 역할을 하 는 해빈의 소실로 인해 연안방재적 측면에서 위협이 되는 등 많은 피해 가능성을 내재하고 있다. 이러한 이유로 해양수산부 는 '연안재해에 대응할 수 있는 안전한 국토환경 조성', '연안공 간의 이용여건 및 가치 제고', 그리고 '연안재해대응을 위한 다 양한 기술개발 및 역량의 증진'등을 성과 목표로 하는 제 2 차 연 안정비 기본계획 변경계획을 수립하여 370 개 사업지구를 대상 으로 1 조 9,844 억원 규모의 연안정비를 실시하고 있다(Ministry of Oceans and Fisheries, 2014). 그러나 지속적인 정비사업 추진 에도 불구하고 사업에 적용된 공법의 예상치 못한 부작용과 기 타 요인 등에 의해 해안침식 피해가 심화되고 있으며, 특히 동 해안 강원 지방의 41 개 연안을 대상으로 수행된 침식 모니터링 결과에 따르면 $\mathrm{C}$ 등급(지형변동 우려) 해안이 13개소, $\mathrm{D}$ 등급(지 형변동 심각) 해안이 22개소로 나타나고 있어 피해를 완화시키 기 위한 대안공법의 마련이 시급한 실정이다(The province of Gangwon, 2013). 위와 같이 점차 증가하는 침식피해로부터 한정 된 국가예산을 활용하여 대응하기 위해서는 국가 주도의 연안 정비사업에서 활용 가능한 저비용 고효율의 침식저감공법을 개 발하는 방법을 제안할 수 있을 것이며, 이는 연안정비 기본계획 의 성과목표와 부합한다.

Received 19 November 2018, revised 13 December 2018, accepted 13 December 2018

Corresponding author Soon-Chul Kwon: +82-51-510-7640, sckwon@pusan.ac.kr ORCID: http://orcid.org/0000-0003-3764-331X

It is noted that this paper is revised edition based on proceedings of The 3rd International water safety symposium in Songdo, Incheon 
침식저감공법의 개발 필요성이 대두됨에 따라 수치해석, 수리 실험, 현장실증테스트를 통한 연구개발이 국내·외에서 활발히 진행되고 있다. 해안식생을 이용해 입사파를 약화시키는 식생 공법과 관련하여 Jeong and $\operatorname{Hur}(2016)$ 는 수치실험을 통해 식생 제원 및 파랑 조건에 따른 파랑감쇠 성능을 분석하였으며, $\mathrm{Kim}$ et al.(2016)은 수리실험을 통해 식생대의 설치유무 및 폭의 영향 에 따른 해안침식 지형변동 경향을 분석하였다.

소상파 일부를 지하투수층을 통해 배제시켜 인파에 의한 침 식을 제어하는 해빈배수공법과 관련하여 Hur et al.(2010)은 3차 원 수치해석기법(LES-WASS-3D)을 이용하여 투수층의 배치 조 건과 입사파의 파고 및 주기 조건 변화에 따른 해빈 내부의 지 하수위변화를 연구하였으며, Ciavola et al.(2008)는 해빈배수공 법이 적용된 이탈리아의 Alassio, Procida, Bibione, Metaponto, 그 리고 Lido Adriano 해안을 대상으로 3년간의 지형변동 모니터링 분석을 수행하여 공법의 타당성을 분석한 사례가 있다.

Kang and Hong(2016)은 해안에서 침식피해를 유발하는 파의 방향을 바꾸어 침식을 완화시키는 파향제어공법을 제안하고 이 를 검토하는 단계의 연구를 수행하였다.

Ferrario et al.(2014)은 Guam 해안에서 실측한 파랑분석 자료 에 근거하여 수심이 얕아 저조시 수면위로 드러나는 거초면 (Reef flat)에서의 파에너지는 산호초 서식지대 전면해상(Fore reef)에 비해 $97 \%$ 저감되며, 대부분의 파에너지가 산호초 서식 지대 상단부분에서 소산된다는 연구결과를 발표하였다. Park et al.(2017)은 인공산호초 구조물의 설치유무에 따른 파고감소효과 와 양빈사의 포착률을 제시하였다.

해안침식 저감공법 개발과 관련된 상기 선행연구들은 공통적 으로 공법 적용에 따른 파의 해석을 중요하게 다루고 있다. 국 내 연안시설 설계에 있어 파랑은 조위, 조류, 표사, 해저지형변 동 등과 함께 고려되는 주요 인자로서 평상파와 폭풍파 조건에 대한 검토가 이루어지고 있다(Ministry of Oceans and Fisheries, 2016). 또한 미국육군공병단(US Army Corp.)은 Shore protection manual의 발간을 통해 구조물 설계편에서 수심변동 및 해안구 조물에 의한 파랑변형의 해석을 위한 평가인자로 파랑전달율 $\left(K_{T}\right)$ 개념을 제시하고 있다.

일반적으로 해안침식이 발생하는 근본원인은 내습파랑 및 해 빈류에 의해 표사의 유실량이 공급량보다 과도해지는 표사수지 불균형에 기인하는데 Kang et al.(2010)은 속초 영랑해안의 건설 현장에서 발생한 국부적 침 - 퇴적 원인으로 해안구조물 시공에 따른 파동장 변화에 따른 표사수급의 불균형을 제시하고 있다. Shin and Hong(2004)은 연안역에서의 해빈변형 예측모델을 개발 함에 있어 3 차원 이동상 실험을 통해 구조물 배후에서 발생하 는 표사이동현상을 규명하였으며, 이는 지형변동 예측에 있어 표사의 거동이 지배적인 사항임을 의미한다. 해안선의 변동을 다룬 최근 연구 사례로 Kim and Lee(2018)는 Robert(1991)의 평 형해빈단면의 개념을 바탕으로 해빈사 입경, 사면경사 등의 조 건에 따른 유입 파에너지와 수렴 해안선 위치 변화를 연계 해 석하는 연구를 수행하였다.

상기 선행연구의 조사- 분석을 통해 해안침식 공법을 평가하 기 위해 침식과 관련된 주요 인자인 파의 해석이 필수적이며, 침식의 원인이 표사수급 불균형임을 감안할 때 지형변동을 해
석하기 위해 해빈사의 침식정도를 분석할 필요가 있음을 확인 하였다. 이에 본 연구에서는 해안침식 피해 완화를 목적으로 개 발한 인공산호초 공법의 성능평가를 위해 2차원 수리실험을 실 시하고자 하며, 파랑감쇠성능과 침식해빈사에 대한 재퇴적을 의미하는 포집율을 산정하여 공법의 현장적용 가능성을 분석하 고자 하였다.

\section{2. 연구방법}

\subsection{2차원 수리실험 Test-bed 제작}

인공산호초 연성공법의 파고저감 및 침식해빈사에 대한 포집 성능을 효과적으로 비교·분석하기 위해 어떠한 공법도 적용되 지 않은 자연해빈, TTP(Tetrapod) 잠제공법, 그리고 인공산호초 공법의 총 3 가지 경우에 대한 Test-bed를 구축하였다. 자연해빈 을 포함한 모든 실험조건의 경우 지형변동 해석을 위한 이동상 실험재료로서 중앙입경 $\left(D_{50}\right)$ 이 $0.4 \sim 0.5 \mathrm{~mm}$ 범위인 주문진표준사 를 $1: 10$ 경사면 상에 $7 \mathrm{~cm}$ 두께로 포설하여 해안지형을 모의하였 다(Fig. 1(a), Fig. 1(d)). 이때 평상파 실험 조건을 기준으로 TTP 잠제공법 Test-bed의 경우 수직높이 $7 \mathrm{~cm}$ 의 TTP 단위체를 사용하 였으며, TTP 단위체를 난적거치하여 폭 $1.1 \mathrm{~m}$, 최상단부의 천단 수심이 $7 \mathrm{~cm}$ 가 되도록 설치하였다(Fig. 1(b), Fig. 1(e)). 인공산호 초 공법의 경우 파랑 저감기능을 가진 파고저감부(Wave trap)와 침식 해빈사의 퇴적기능을 가진 모래포집부(Sand trap)로 나누어 진 인공산호초 단위체를 사용하여 TTP 잠제공법과 동일한 형상 을 갖도록 폭 $1.1 \mathrm{~m}$, 최상단부에서의 천단수심이 $7 \mathrm{~cm}$ 가 되는 Test-bed를 제작하여 실험에 활용하였다(Fig. 1(c), Fig. 1(f)).

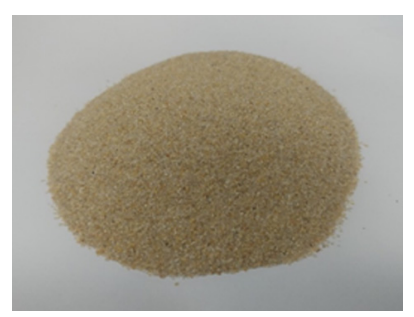

(a) Joomoonjin silika sand

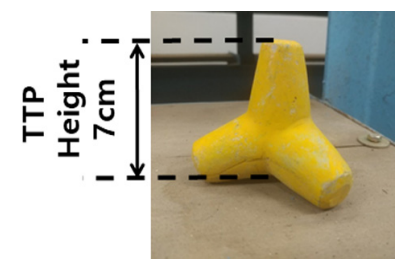

(b) TTP unit

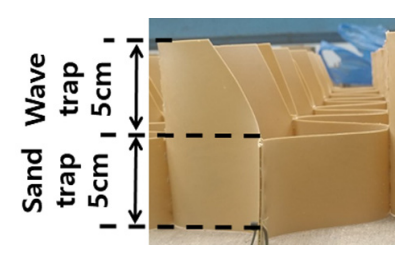

(c) ACRs unit

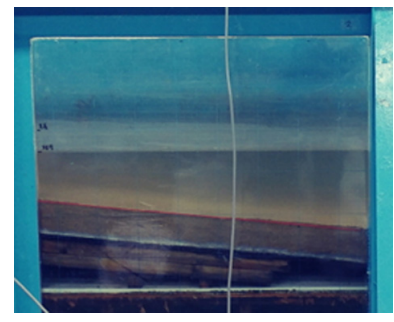

(d) Natural beach

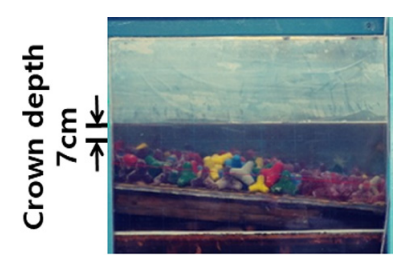

(e) TTP method

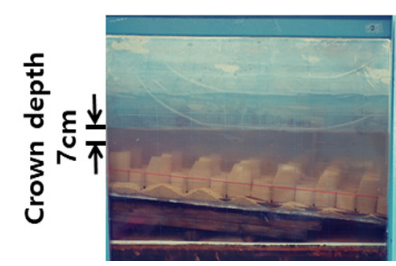

(f) ACRs method
Fig. 1 Materials and structures for the experiment 


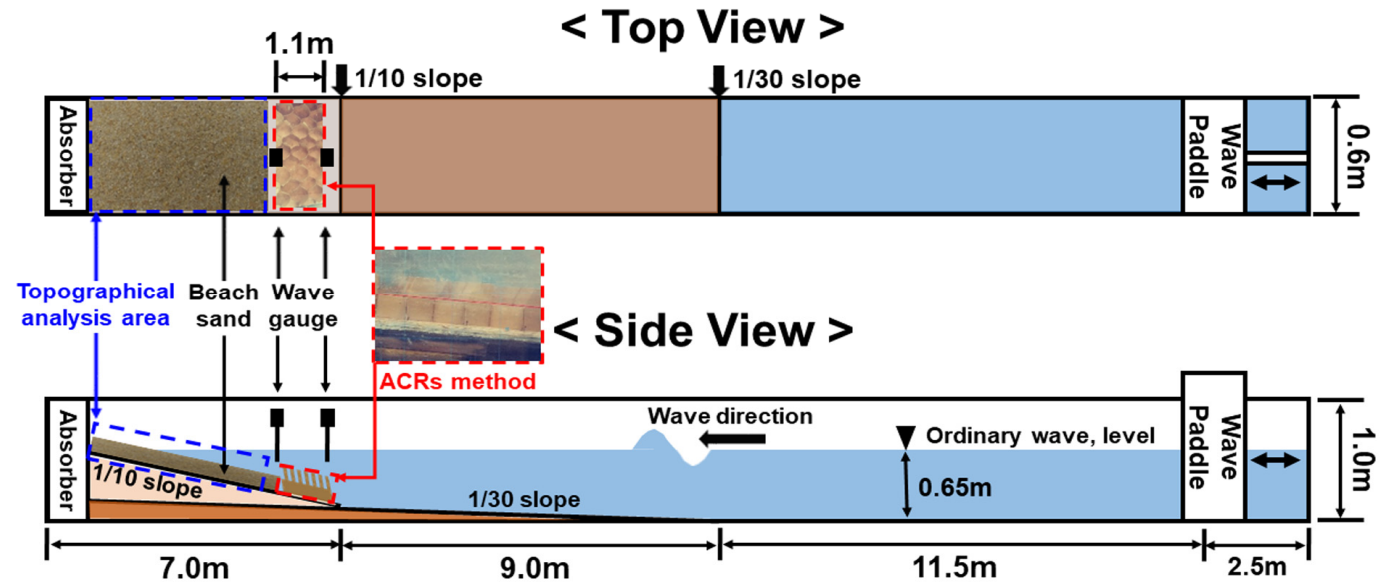

Fig. 2 Experimental setup for 2D experiment (Note that we rescaled the scheme for better understanding.)

\section{2 수리실험 단면설계 및 실험파 조건}

공법의 성능평가를 위한 수리실험 수행을 위해 길이 $30 \mathrm{~m}$, 폭 $0.6 \mathrm{~m}$, 깊이 $1 \mathrm{~m}$ 의 조파수조 내부에 $1 / 30$ 경사면을 설치하였고, 그 상단면에 $1 / 10$ 경사면을 추가적으로 조성하여 외해에서 파랑이 내 습하며 천수 및 쇄파가 발생하는 실제 해안을 모의하였다(Fig. 2). 또한 해양파가 다양한 파고와 주기를 갖는 파랑의 무수한 중첩에 의한 합성파임을 고려하여 $0-4$ 초 주기의 불규칙파를 발생시킬 수 있는 조파시스템을 활용하여 평상파와 폭풍파를 모의하였다. 이때 입사파를 기준으로 평상파는 $65 \mathrm{~cm}$ 의 수위에서 유의파고가 $8.0-9.0 \mathrm{~cm}$, 유의주기가 1.2 1.3초 이며, 폭풍파는 동일한 공법 적용 위치에서 $72 \mathrm{~cm}$ 의 수위로 유의파고가 $11.0 ~ 12.0 \mathrm{~cm}$ 이고 유의주기가 1.3 1.4초인 파를 실험파로 사용하여 파랑 내습조건에 따른 공법별 침식 방지성능을 검토하였다. 조파실험은 각 실험케이스별로 총 20 시간의 실험을 수행하였으며, 4 시간 단위의 조파간격에 따라 파 랑관측 및 지형변동 경향을 분석하였다.

\section{3 공법 조건별 파랑 감쇠성능 분석방법}

인공산호초 공법의 파랑감쇠 성능을 분석하기 위해 Kenek사
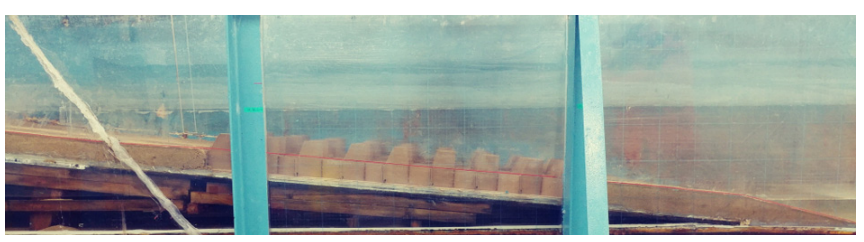

(a) Initial seabed condition for ACRs experiment

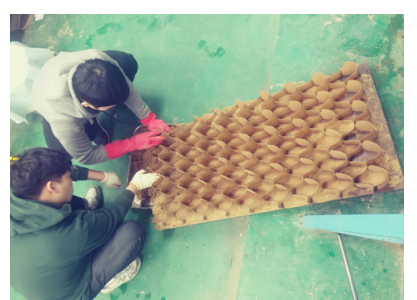

(d) Collection of the beach sand from the ACRs

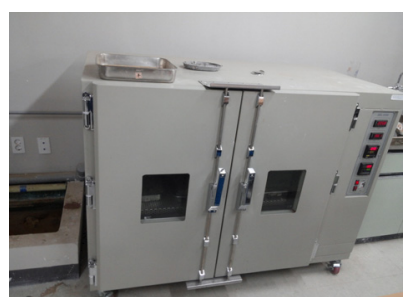

(e) Drying the beach sand under high temperature

의 제품 중 반응이 빠르고 관측오차가 적은 용량식 파고계 $(\mathrm{CH}$ $608 \mathrm{E}$ 모델)와 파고계 센서(CHT6-30E 모델)를 사용하여 1초당 20 회의 수위 Data를 취득하여 파랑분석에 활용하였다. 이때 파 의 용이한 취급을 위해 실험파가 가지는 파고와 주기의 불규칙 성을 하나의 값으로 대표할 수 있는 유의파(Significant wave)법 을 적용하였다. 공법 적용지점 전·후면에서의 측정 및 분석된 파고와 주기를 바탕으로 식 (1)과 같이 전달파고 $\left(H_{t}\right)$ 에 대한 유 의파고 $\left(H_{i}\right)$ 의 비율을 나타내는 파고전달율 $\left(K_{T}\right)$ 을 사용하여 파 랑감쇠성능을 제시하였다.

$$
K_{T}=\frac{H_{t}}{H_{i}}
$$

\section{4 지형변동 경향분석 및 해빈사 포집율 산정}

해저지형의 변동경향을 분석하고 인공산호초 공법에 의한 침 식 해빈사 포집율을 정량적으로 산정하기 위해 조파에 따른 표 사 거동을 분석하는 이동상 실험을 수행하였다. 효율적인 해빈 사의 거동 관측을 위해 2 차원 조파수조 전면의 강화유리에 투

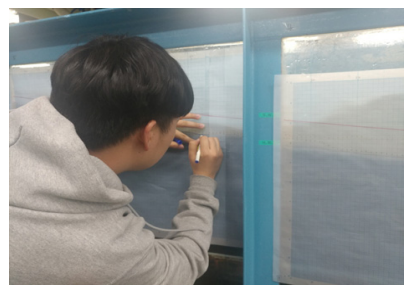

(b) Measurement of the height of beach sand

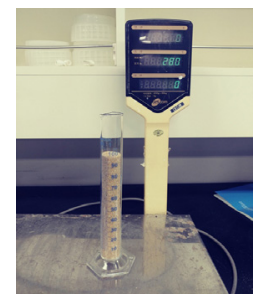

(f) Measurement of weight per unit volume

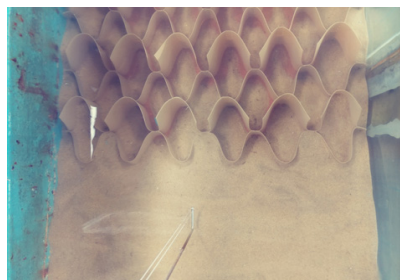

(c) Beach sand sedimentation in ACRs structure

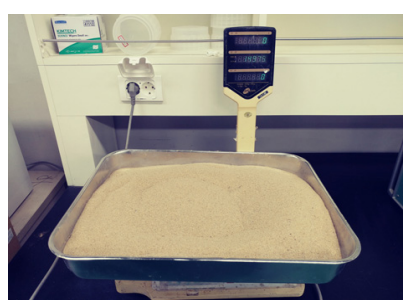

(g) Weight measurement of the beach sand

Fig. 3 Analyzing process of the topographical change and efficiency of beach sand capture 
명 방안지를 부착하였고, $1: 10$ 경사면 상에 설치된 초기해안선 (Fig. 3(a)) 중 표사이동이 발생할 것으로 예상된 $4.5 \mathrm{~m}$ 구간에 대 해 모래높이를 $1 \mathrm{~cm}$ 단위로 측정(Fig. 3(b))하여 조파에 따른 해 안선 변동경향을 해석하고, 초기해안선 대비 20시간 이후의 침 식된 체적을 산정하였다.

인공산호초 공법 적용에 따른 해빈사 포집율을 산정하는 과 정에서는 수조 전면의 투명 방안지를 활용할 수 없기 때문에 단위체적중량 개념을 도입하여 구조체 내부에 퇴적된 체적을 산정하였다. 이를 위해 조파실험 종료 후 구조체 내부에 퇴적된 해빈사(Fig. 3(c))가 유실되지 않도록 수거한 뒤(Fig. 3(d)) 퇴적 해빈사를 $110^{\circ} \mathrm{C}$ 조건에서 48 시간 건조하였다(Fig. 3(e)). 이후 건 조된 침식 해빈사를 우선적으로 $100 \mathrm{~mL}$ 의 메스실린더를 이용해 해빈사의 단위체적중량 $\left(\gamma_{S}\right)$ 을 산정하였으며(Fig. 3(f)), 건조된 해 빈사의 총 중량 $\left(W_{S}\right)$ 을 측정하고 이를 식 (2)와 같이 단위체적중 량과 역산하여 인공산호초 구조체 내부에 퇴적된 해빈사 포집 체적 $\left(V_{C}\right)$ 을 산정하였다.

$$
V_{C}\left(\mathrm{~cm}^{3}\right)=\frac{W_{S}(g f)}{\gamma_{S}\left(g f / \mathrm{cm}^{3}\right)}
$$

이후 최종적으로 전체 침식체적 $(\Delta V)$ 에 대한 해빈사 포집체 적 $\left(V_{C}\right)$ 의 비율을 의미하는 해빈사 포집율 $\left(E_{C}\right)$ 을 식 (3)과 같이 산정하였다.

$$
E_{C}(\%)=\frac{V_{C}\left(\mathrm{~cm}^{3}\right)}{\Delta V\left(\mathrm{~cm}^{3}\right)} \times 100
$$

\section{3. 적용 공법별 파랑 감쇠성능 비교}

Table 1은 공법 적용조건에 따른 입사파와 전달파의 파고 및 주기, 그리고 파랑전달율에 대한 분석결과를 나타내고 있다. 이 때 각 공법이 적용된 경우의 입사파고 분석결과 평상파의 평균 값은 $8.69 \mathrm{~cm}$ (표준편차 0.30 )이고, 폭풍파는 평균값은 $11.29 \mathrm{~cm}$ (표 준편차 0.20 )로 큰 편차 없이 일정한 값이 나타났으며, 이는 실 험파를 불규칙파로 사용하였음에도 안정적인 조파가 이루어진 것이 확인되었다. 평상파 조건에서 인공산호초 공법은 파고전 달율이 0.74 로 공법이 적용되지 않은 자연해빈과 TTP 공법에 비해 구조물 배후에서 파고 감쇠가 가장 크게 나타났다. 이러한 경향은 폭풍파 실험조건에서도 재현되었는데 인공산호초 공법 이 적용된 경우는 파고전달율이 0.86 으로 분석되어 상대적으로 공법 적용 대상지 배후에서의 파고저감 기능이 우수한 것으로 분석되었다. 이는 인공산호초 구조체 선단 상에서 천단수심의 감쇠에 따라 파랑이 강제 쇄파되는 효과에 기인한 것으로 판단 된다.

평상파와 폭풍파 내습에 따른 파고전달율을 추가적으로 비교 한 결과, 폭풍파 조건에서는 모든 공법 적용케이스에서 파랑전 달효과가 감소하는 경향이 보이고 있는데 TTP 공법 적용 시 입 사파 대비 전달파의 감쇠가 발생하지 않았으며, 특히 아무 공법 도 적용되지 않은 자연해빈의 경우 전달파고가 입사파고에 비
Table 1 Results of the wave analysis

\begin{tabular}{ccccc}
\hline \hline Wave condition & Value & $\begin{array}{c}\text { Natural } \\
\text { beach }\end{array}$ & $\begin{array}{c}\text { TTP } \\
\text { method }\end{array}$ & $\begin{array}{c}\text { ACRs } \\
\text { method }\end{array}$ \\
\hline & $H_{i}[\mathrm{~cm}]$ & 8.88 & 8.70 & 8.90 \\
Ordinary wave & $H_{t}[\mathrm{~cm}]$ & 7.76 & 7.83 & 6.59 \\
condition & $K_{t}[\mathrm{~cm}]$ & 0.87 & 0.90 & 0.74 \\
& $T_{i}[\mathrm{~s}]$ & 1.26 & 1.23 & 1.26 \\
& $T_{t}[\mathrm{~s}]$ & 1.35 & 1.32 & 1.31 \\
\hline \multirow{2}{*}{ condition } & $H_{i}[\mathrm{~cm}]$ & 11.27 & 11.12 & 11.58 \\
& $H_{t}[\mathrm{~cm}]$ & 12.05 & 11.03 & 9.94 \\
& $K_{t}[\mathrm{~cm}]$ & 1.07 & 0.99 & 0.86 \\
& $T_{i}[\mathrm{~s}]$ & 1.30 & 1.28 & 1.31 \\
& $T_{t}[\mathrm{~s}]$ & 1.39 & 1.35 & 1.37 \\
\hline
\end{tabular}

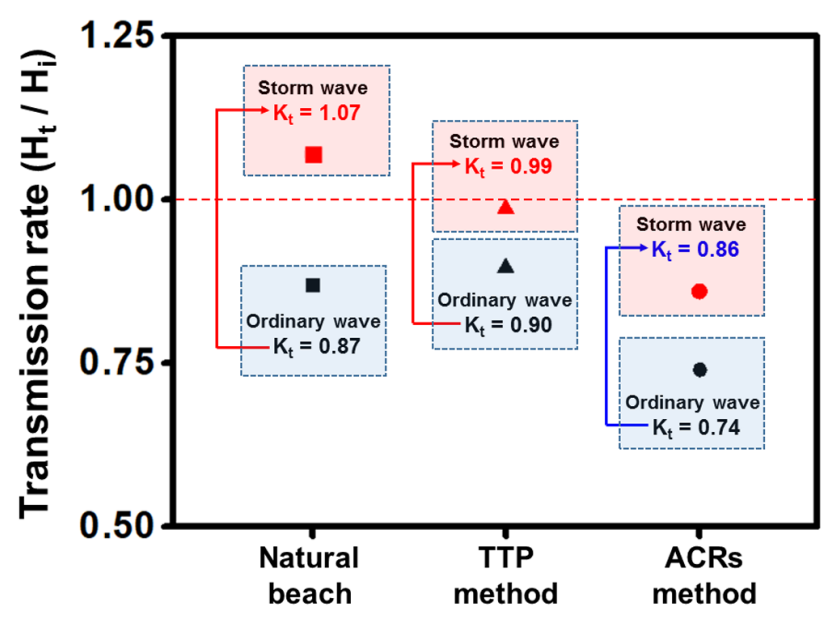

Fig. 4 Decline tendency of wave transmission effects under storm wave conditions

해 7\% 증가하는 등 천수 발생에 따라 파랑감쇠효과가 약화되고 있다(Fig. 4). 해안침식 방지공법의 부재로 인해 해안선과 가까 운 지점에서 권파형의 큰 쇄파가 발생할 경우 강한 쇄파에너지 에 의해 상당한 해저토사가 유실되며 이는 해안침식 가능성을 내재하고 있는 만큼 침식피해 방지를 위한 적절한 공법의 적용 이 필요할 것으로 판단된다.

\section{4. 적용 공법 별 지형변동 경향 및 인공산호초 공법의 해빈사 포집성능 분석}

\section{1 자연해빈(공법 미적용) 조건에서의 지형변동}

Fig. 5(a)와 Fig. 6(a)는 자연해빈(공법 미적용)상태에서 평상파, 폭풍파 조건에 대한 해빈변화를 나타낸 것으로 종축은 경사면 으로부터의 모래 높이를, 그리고 횡축은 $1: 10$ 경사면과 $1: 30$ 경 사면이 만나는 수평좌표 상의 기준점으로부터 수평방향의 거리 를 의미한다. 각 실험은 1 회당 4 시간 간격으로 5 회 실시하여 총 20시간 진행되었는데, 이때 Fig. 5와 Fig. 6에서 검은선은 1:10경 사면, 빨간선은 조파 전 모래높이, 그리고 주황선, 초록선, 파란 


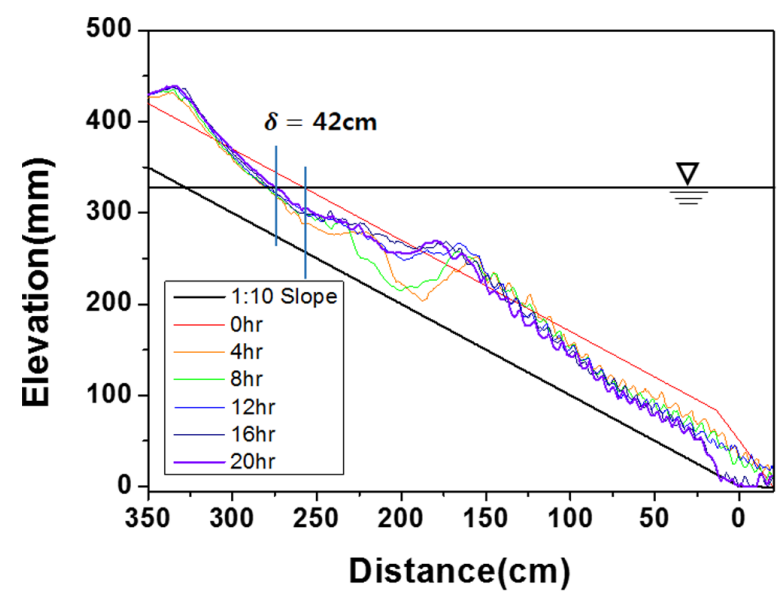

(a) Natural beach

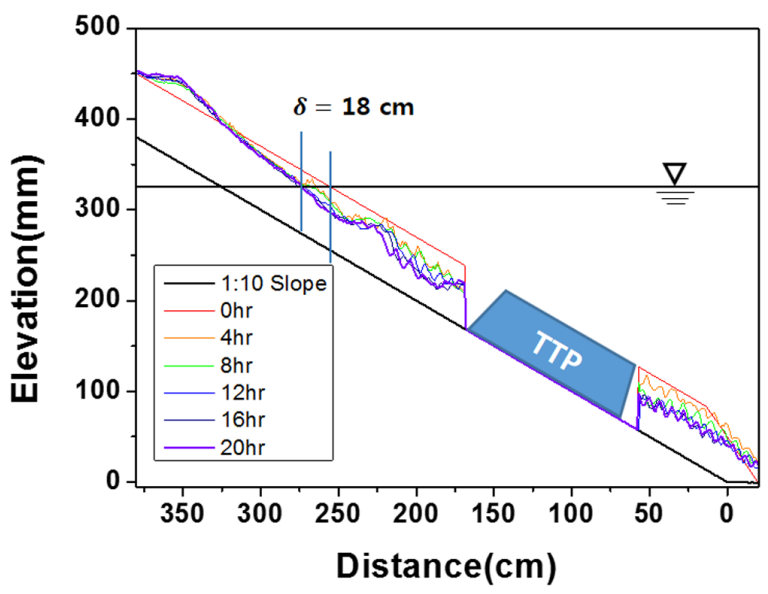

(b) TTP method

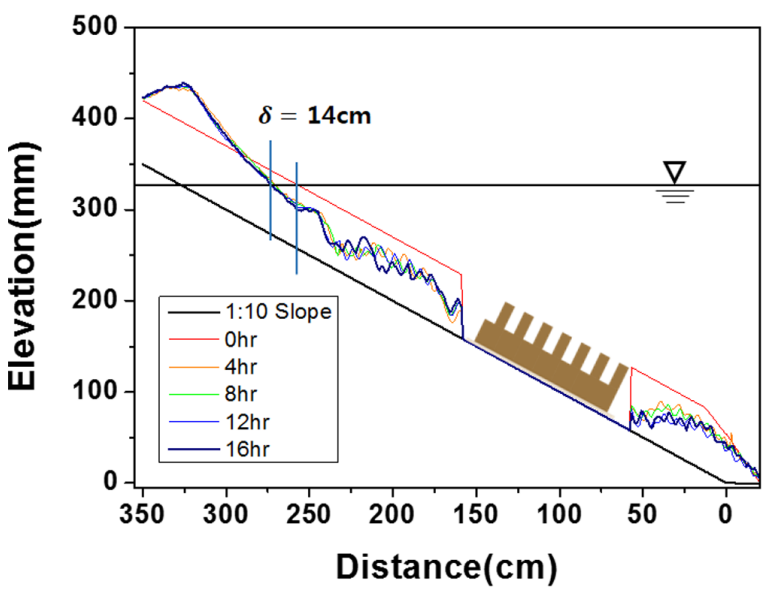

(c) ACRs method

Fig 5. Topographical variation under ordinary wave

선, 남색선, 보라선은 각각 조파 4시간, 8 시간, 12 시간, 16시간, 20 시간 이후1:10 경사면을 기준으로 하는 모래 높이를 의미한 다. Fig. 5(a)는 공법 미적용 구간의 평상파 조건 실험결과를 나 타내는데 초기 해안선 지점에서 $4.6 \mathrm{~cm}$ 깊이의 침식이 발생하였 고, 해안선이 $42 \mathrm{~cm}$ 후퇴 $(\delta=42 \mathrm{~cm})$ 하였다. 또한 $177 \mathrm{~cm}$ 지점에서 연안사주가 발생하였고, 최대높이는 $2.1 \mathrm{~cm}$ 로 나타났다. 이는 해 안선의 소류사는 육지 쪽으로 표사이동이 발생하여 퇴적형의

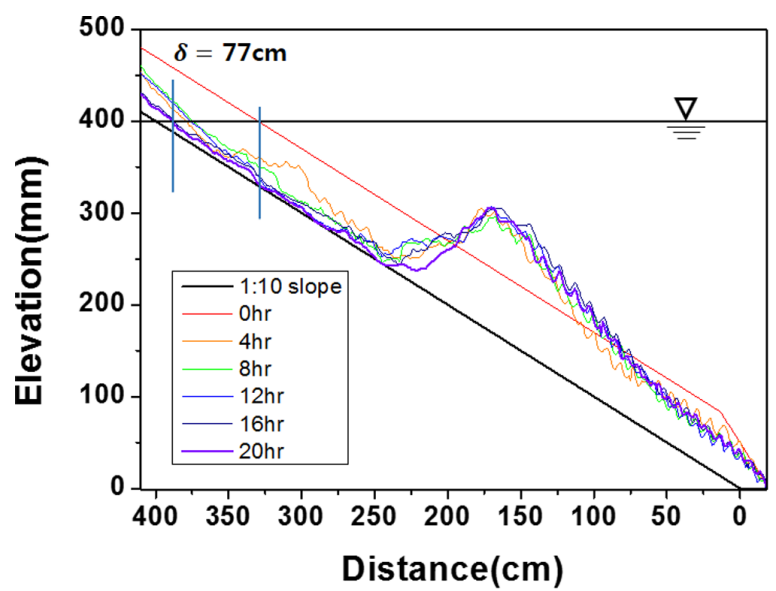

(a) Natural beach

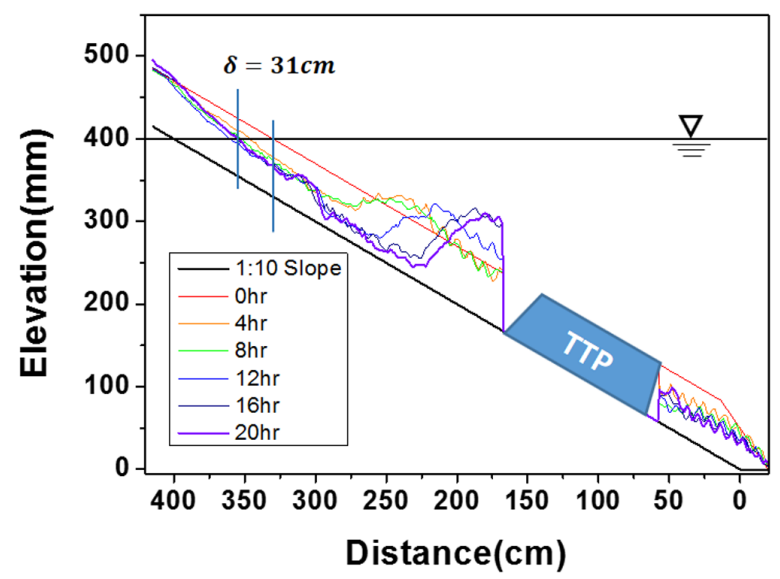

(b) TTP method

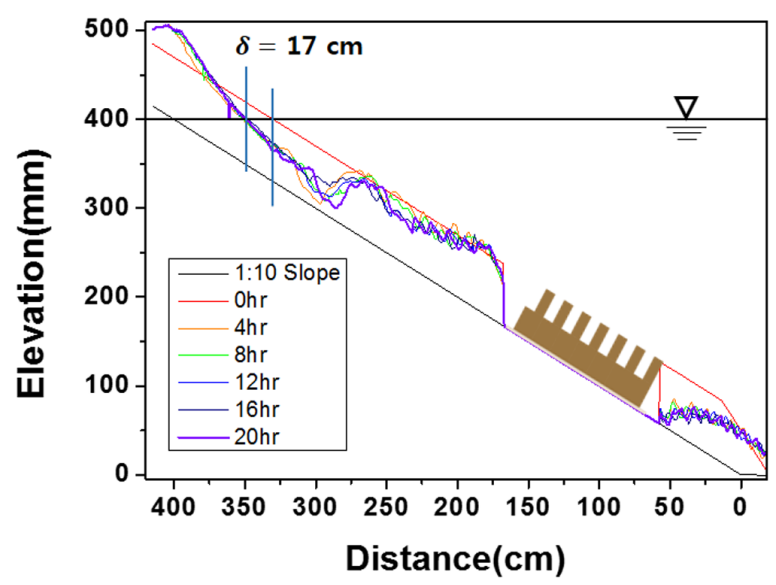

(c) ACRs method

Fig 6. Topographical variation under storm wave

해빈단면이 형성되었고, 해안선의 부유표사는 이안방향의 표사 이동이 발생하여 침식형의 해빈단면이 나타났다. Fig. 6(a)는 공 법 미적용 구간의 폭풍파 조건 실험결과를 나타내는데 초기 해 안선 지점에서 $6.5 \mathrm{~cm}$ 깊이의 침식이 발생함과 동시에 해안선이 $77 \mathrm{~cm}$ 후퇴하였으며, 연안사주는 평상파 실험결과와 유사하게 $171 \mathrm{~cm}$ 지점에서 발생하였는데 그 최대높이는 $6.5 \mathrm{~cm}$ 로 나타났다. 폭풍파 조건에서는 해안선일대에서 대규모 침식이 발생하여 이 
안방향에 연안사주를 생성시킨 것으로 판단된다.

\subsection{TTP 잠제 공법 적용 시 지형변동}

Fig. 5(b)와 Fig. 6(b)는 각각 TTP 공법이 적용되었을 때 평상 파 및 폭풍파 조건에서의 지형변화를 나타낸다. 평상파조건의 경우 초기 해안선 지점에서 $2.7 \mathrm{~cm}$ 깊이의 침식이 발생하였고, 해안선의 위치는 $18 \mathrm{~cm}$ 후퇴하였다. 연안사주는 $330 \mathrm{~cm}$ 부근에서 발생하였으며 최대높이는 $2.3 \mathrm{~cm}$ 로 나타났다. TTP 잠제 설치 시 자연해빈 상태보다 상대적으로 해안선 위치는 약 $24 \mathrm{~cm}$ 만큼 덜 침식되었고, 정선에서 수직방향의 침식 깊이가 $3.1 \mathrm{~cm}$ 감소하는 것으로 나타났다. 폭풍파 조건에서는 초기 해안선 지점에서 $3.1 \mathrm{~cm}$ 깊이의 침식이 발생하였고, 해안선은 $31 \mathrm{~cm}$ 후퇴하였다. 이때 TTP 잠제 설치지점 전면 $180 \mathrm{~cm}$ 부근에서 최대높이 $6.5 \mathrm{~cm}$ 의 큰 연안사주가 생성되었다. 또한 자연해빈 상태에 비하여 해 안선이 $46 \mathrm{~cm}$ 만큼 덜 침식되었고, 초기 해안선 지점에서 깊이 가 약 $3.7 \mathrm{~cm}$ 감소하였다. 결과적으로 TTP 잠제 설치 시 자연해 빈상태보다 해안선 위치는 전진하고, 해안선 주변의 침식은 감 소하는 것으로 관측되었다. 이러한 현상은 잠제 설치에 따른 공 법 적용 배후구간에서의 파랑저감 효과로 판단된다.

\section{3 인공산호초 공법 적용 시 지형변동}

Fig. 5(c)와 Fig. 6(c)는 각각 인공산호초 공법이 적용되었을 때 평상파 및 폭풍파 조건에서의 지형변화를 나타낸다. 평상파 조건 의 경우 초기 해안선 지점에서 $2.4 \mathrm{~cm}$ 깊이의 침식이 발생하였고, 해안선은 $14 \mathrm{~cm}$ 후퇴하였다. 연안사주는 해안선 부근 $326 \mathrm{~cm}$ 에서 발생하였으며 최대높이는 $4.5 \mathrm{~cm}$ 로 나타났다. 폭풍파 조건에서는 초기 해안선 지점에서 $3.2 \mathrm{~cm}$ 의 깊이의 침식이 발생하였고, 해안 선은 $17 \mathrm{~cm}$ 후퇴하였다. 이는 인공산호초 공법이 적용된 경우의 해안선은 자연해빈 상태를 기준으로 할 때 평상파의 경우 $28 \mathrm{~cm}$, 폭풍파의 경우 $60 \mathrm{~cm}$ 만큼의 해안선 후퇴룰 방지한 것을 의미하 며, 해안선 부근에서의 표사이동이 상당히 저감된 것으로 보인 다. 또한 폭풍파와 같은 고파랑 내습 시 TTP 잠제보다 해안선이 $14 \mathrm{~cm}$ 덜 침식되는 효과를 나타내며, 더 큰 연안사주를 발생시키 지 않았다. 이는 인공산호초 구조적 특성상 모래포집부에 표사가 침식되지 못하도록 포집하여 완만한 해빈경사가 유지된 것에 기 인한 것으로 사료된다. 결과적으로 지형변동실험 결과에 대한 상 호비교결과 인공산호초 공법 적용 시 가장 안정된 해빈 형상을 유지한 것으로 나타났다.

\section{4 침식저감율 및 포집율 산정}

평상파 및 폭풍파 조건에 따른 해빈사의 침식저감율과 포집 율을 구하기 위해 조파 전과 후의 해빈사 체적을 측정하여 파 랑 내습에 의해 유실된 해빈사 침식량을 산정하였다. 이후 코랄 셀 내부에 포집된 해빈사 포집량을 측정하였고, 식 (4)를 이용 하여 침식저감율 $\left(E_{E R}\right.$, Efficiency of erosion reduction)을 계산하 였다.

$$
E_{E R}=\frac{V_{N}-\Delta V+V_{C}}{V_{N}} \times 100
$$

Table 2는 각각의 실험조건에 따른 총 해빈사 침식량 $\left(\Delta V, \mathrm{~cm}^{3}\right)$, 해빈사 포집체적 $\left(V_{C}, \mathrm{~cm}^{3}\right)$, 침식저감율 $(\%)$, 해빈사 포집율 $\left(E_{C}, \%\right)$ 을 나타낸다. 실험결과 자연해빈에서의 해빈사 침식량 $\left(V_{N}, \mathrm{~cm}^{3}\right)$ 은 평상파 조건에서 $32,902 \mathrm{~cm}^{3}$, 폭풍파 조건에서 $63,846 \mathrm{~cm}^{3}$ 으로 폭풍 파 조건에서 2 배 이상의 침식이 발생하였다. 침식저감율은 평상파 조건에서 인공산호초 $(34.71 \%)>\operatorname{TTP}(11.43 \%)$ 로 나타났으며, 폭풍 파 조건에서도 마찬가지로 인공산호초 $(71.00 \%)>\mathrm{TTP}(54.24 \%)$ 로 인공산호초공법 적용 시 가장 높은 침식저감을 보이는 것으로 나타 났다. 침식저감율은 평상파 조건에서 인공산호초(34.71\%) > $\mathrm{TTP}(11.43 \%)$ 로 나타났으며, 폭풍파 조건에서도 마찬가지로 인공산 호초 $(71.00 \%)>\mathrm{TTP}(54.24 \%)$ 로 인공산호초 공법 적용 시 가장 높은 침식저감을 보이는 것으로 나타났다. 해빈사 포집율의 경우 총 해빈 사 침식량 대비 $23.98 \%$ (평상파), $35.48 \%$ (폭풍파)의 포집성능을 나 타냈다. 결과적으로 연성구조의 모래포집부를 가지는 공법의 특성 때문에 외해로 유실되는 해빈사를 포집하여 해빈침식을 저감시키 고, 상대적으로 안정된 해빈형상을 유지한 것으로 판단된다.

\section{5. 결 론}

본 논문에서는 연안침식 피해 대응을 위해 개발한 인공산호 초 공법의 파랑 제어 및 침식해빈사 포집성능을 정량적으로 분 석하기 위해 2차원 수리실험을 수행하였으며, 주요 연구결과는 다음과 같다.

(1) 평상파 조건에 대한 실험결과 파고전달율은 인공산호초 공법은 0.74 로 공법이 적용되지 않은 자연해빈과 TTP공법 적용 사례에 비해 우수한 파랑 감쇠성능을 나타냈다. 폭풍파 조건에

Table 2 Results of the topographical analysis for each experimental cases

\begin{tabular}{ccccc}
\hline \hline & $\begin{array}{c}\text { Total beach } \\
\text { sand erosion } \\
\left(\Delta V, \mathrm{~cm}^{3}\right)\end{array}$ & $\begin{array}{c}\text { Efficiency of erosion } \\
\text { reduction } \\
\left(E_{E R}, \%\right)\end{array}$ & $\begin{array}{c}\text { Volume of captured } \\
\text { beach sand } \\
\left(V_{C}, \mathrm{~cm}^{3}\right)\end{array}$ & $\begin{array}{c}\text { Efficiency of beach } \\
\text { sand capture } \\
\left(E_{C}, \%\right)\end{array}$ \\
\hline $\begin{array}{c}\text { (a) T.T.P under } \\
\text { ordinary wave }\end{array}$ & 29,142 & 11.43 & - & - \\
$\begin{array}{c}\text { (b) T.T.P under } \\
\text { storm wave }\end{array}$ & 41,394 & 54.24 & - & - \\
$\begin{array}{c}\text { (c) ACRs under } \\
\text { ordinary wave } \\
\text { (d) ACRs under }\end{array}$ & 28,260 & 34.71 & $6,776.7$ & 23.98 \\
storm wave & 28,693 & 71.00 & $10,179.3$ & 35.48 \\
\hline
\end{tabular}


서 TTP 공법은 파랑전달율이 0.99 로 감쇠효율이 거의 나타나지 않았으며, 특히 자연해빈에서는 배후에서의 파고가 $7 \%$ 증가하 였다. 이에 비해 인공산호초 공법이 적용된 경우의 파랑전달율 은 0.86 으로 나타나 자연해빈조건 및 $\mathrm{TTP}$ 공법과 비교하여 구조 물 배후에서 파고감쇠효과가 가장 큰 것으로 나타났다.

(2) 파랑조건 별 지형변동분석결과, 인공산호초공법 적용 시 의 해안선은 자연해빈 조건에 비해 평상파 조건에선 $28 \mathrm{~cm}$, 폭 풍파 조건에선 $60 \mathrm{~cm}$ 만큼 침식을 완화하는 효과를 보였다. 또 한 자연해빈조건에서는 침식된 표사에 의해 외해 측에서 연안 사주가 만들어진 것에 비해, 인공산호초 공법 적용 시 해안선부 근에 연안사주가 발생하는 등 해안선 후퇴를 완화하는 효과가 나타났다. 또한 인공산호초 공법 적용 시 폭풍파 조건에서 약 $71.0 \%$ 의 침식저감율과 $35.5 \%$ 의 해빈사포집율을 나타냈다.

본 연구에서는 2 차원 수리실험을 통해 파고전달율과 해빈사 침식방지성능을 분석하였으며, 이를 통해 연안침식피해 대응을 위한 인공산호초공법의 현장 적용 잠재성을 확인할 수 있었다.

향후 연구에서는 3 차원 평면 실험을 통해 인공산호초 구조체 제원, 개구부 간격 등의 실험조건에 대한 파랑 및 지형변동 영 향 등을 추가적으로 검토하여 공법의 최적설계를 수행하고자 한다. 지속적인 연구개발을 통해 인공산호초 공법의 최적 설계 기준이 도출되고, 공법 개선을 통해 연안침식 방지성능이 향상 된다면 침식피해를 겪는 현장에 적용되어 피해를 완화하는데 기여할 수 있을 것으로 판단된다.

\section{후 기}

이 논문은 2018년 해양수산부 재원으로 해양수산과학기술진 흥원의 지원을 받아 수행된 연구임(연안침식 관리 및 대응기술 실용화)

\section{References}

Ciavola, P., Vicinanza, D., Fontana, E., 2008. Beach Drainage as a Form of Shoreline Stabilization: Case Studies in Italy. Proceedings of the $31^{\text {st }}$ International Conference on Coastal Engineering, Hamburg Germany, 2646-2658.

Ferrario F., Beck, M.W., Storlazzi, C.D., Micheli, F., Shepard, C.C., Airoldi, L., 2014. The Effectiveness of Coral Reefs for Coastal Hazard Risk Reduction and Adaptation. Nature Communications, 5(3794), 1-9.
Hur, D.S., Lee, W.D., Jeon, H.S., 2010. A Study on Beach Stabilization by Laying Drainage Layer. Journal of the Korean Society of Cilvil Engineers, 30(3), 325-335.

Jeong, Y.M., Hur, D.S., 2016. Numerical Experiment of Wave Attenuation Considering Behavior of Vegetation Zone. Journal of Korean Society of Coastal and Ocean Engineers, 28(4), 232-239.

Kang, Y.K., Park, H.B., Yoon, H.S., 2010. Shoreline Changes Caused by the Construction of Coastal Erosion Control Structure at the Youngrang Coast in Sockcho, East Korea. Journal of the Korean Society for Marine Environmental Engineering, 13(4), 296-304.

Kang, Y.K., Hong, C.B., 2016. Development of New Coastal Erosion Management Method using Wave Direction Control System(1); New CeM: Tendency of Coastal Erosion and Measures, and Suggestion of New CeM. Journal of Coastal Disaster Prevention, 3(1), 14-35.

Kim, B.M., Jeon, Y.H., Yoon, H.S., 2016. A Hydraulic Experiment Using Artificial Seaweed for Coastal Erosion Prevention. Journal of the Korean Society for Marine Environment and Energy, 19(4), 266-273.

Kim, T.K., Lee, J.L., 2018. Analysis of Shoreline Response due to Wave Energy Incidence Using Equilibrium Beach Profile Concept. Journal of Ocean Engineering and Technology, 32(2), 116-122.

Ministry of Oceans and Fisheries, 2014. The Second Coastal Maintenance Basic Plan Change Plan.

Ministry of Oceans and Fisheries, 2016. Manual of design Standard and Explanation for Offshore Facilities.

Park, S.K., Park, H.B., Kim, Y.H., 2017. Experimental Study on Effectiveness of Wave Reduction and Prevention Erosion of Nourishment Sand Using the Cell Group. Journal of Korean Society of Coastal and Ocean Engineers, 29(5), 269-277.

Robert, G.D., 1991. Equilibrium Beach Profiles: Characteristics and Applications. Journal of Coastal Research, 7(1), 53-84.

Shin, S.H., Hong, K., 2004. An Experimental Study of Sediment Transport Patterns behind Offshore Structure. Journal of the Korean Society for Marine Environmental Engineering, 7(4), 207-215.

The Province of Gangwon, 2013. Final Report of the Coastal Erosion Monitoring 2012. 